\title{
A Study of Chain-Length Effect on Helical Screw Sense in Peptides Having an $\mathrm{N}$-Terminal L-Leu Residue
}

\author{
Yoshihito InAI, ${ }^{\dagger}$ Satoru AshitaKa, and Tadamichi HirabaYashi \\ Department of Environmental Technology and Urban Planning, \\ Graduate School of Engineering, Nagoya Institute of Technology, \\ Gokiso-cho, Showa-ku, Nagoya 466-8555, Japan
}

(Received July 29, 1998)

\begin{abstract}
In order to clarify which helical screw sense is dominated depending on chain-length of peptides when an L-residue is introduced into the $N$-terminal position of achiral helical segments, we prepared three kinds of peptides I-III: Boc-L-Leu-(Aib- $\Delta \mathrm{Phe})_{n}-\mathrm{Aib}-\mathrm{OMe}(n=2$-4) I-III (Boc, $t$-butoxycarbonyl; Aib, $\alpha$-aminoisobutyric acid; $\Delta$ Phe, $Z$-dehydrophenylalanine; OMe, methoxy). Here the segment -(Aib- $\Delta \mathrm{Phe})_{n}-\mathrm{Aib}-\mathrm{OMe}$ was used for an achiral backbone com-

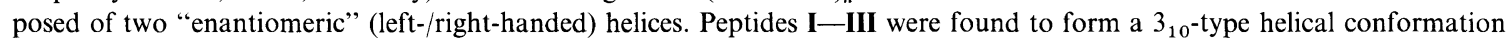
in chloroform, from the position of amide I band in FT-IR spectra and solvent accessibility of NH resonances in ${ }^{1} \mathrm{H}$ NMR measurement. CD spectra of peptides I-III showed exciton couplets around $280 \mathrm{~nm}$ with a positive peak at longer wavelengths in chloroform, acetonitrile, methanol, and tetrahydrofuran. The sign of exciton couplets indicates that the main-chains prefer a left-handed screw sense. Consequently, an $N$-terminal L-Leu residue induces a left-handed screw sense preferentially, irrespective of chain lengths for achiral helical segments (5-9 residues). This result could be supported by conformational energy calculation on acetyl-L-Leu-(Aib- $\Delta \mathrm{Phe})_{4}-\mathrm{Aib}-\mathrm{OMe}$, in which a left-handed helical conformation was predominant. Also, in the lowest-energy left-handed helix, an $N$-terminal L-Leu residue takes an irregular conformation that deviates from a left-handed $3_{10^{-}} / \alpha$-helical region in conformational space of $(\phi, \psi)$.

KEY WORDS Helical Screw Sense / Chain-Length Effect / Achiral Helical Segment / Effect of $N$-Terminal L-Residue / CD Spectroscopy / Conformational Energy Calculation /
\end{abstract}

Most of L-amino acid residues are well recognized to prefer a right-handed screw sense in helical segments of proteins or peptides. On the other hand, L-residue was rarely found to induce a left-handed screw sense for several peptides containing achiral helicogenic residues, $Z$-dehydrophenylalanine $(\Delta \mathrm{Phe})^{1-13}$ or $\alpha$-aminoisobutyric acid (Aib) ${ }^{14,15}$ :<smiles>CN/C(=C\c1ccccc1)COC</smiles>

$\triangle$ Phe<smiles>CNC(C)(C)C(C)=O</smiles>

Aib
Scheme 1. $\Delta$ Phe and Aib residues.

For example, a left-handed $3_{10}$-helix in solution was seen in Ac- $\Delta$ Phe-Gly- $\Delta$ Phe-L-Ala-OMe (Ac, acetyl; OMe, methoxy $)^{13}$ or Boc-L-Pro-Aib-L-Ala-Aib-L-Ala-OMe (Boc, $t$-butoxycarbonyl). ${ }^{16}$ Left-handed $3{ }_{10}$-helices have also been observed in the crystalline state for Aib peptides containing an L-residue in the C-terminal position. ${ }^{16-18}$ Boc-L-Ala- $\Delta$ Phe-Gly- $\Delta$ Phe-L-Ala-OMe showed reversible screw sense inversion of $3_{10}$-helix, depending on solvent and temperature conditions. ${ }^{5,13}$ Also, Boc-LAla- $\Delta$ Phe- $\Delta$ Phe-NMA (NMA, $N$-methyl amide) took an incipient $3{ }_{10}$-helix of both left- and right-handed screw senses in the solid. ${ }^{12}$ Thus, L-residue seems to show the character of left-handed screw sense when it is relatively C-terminally introduced to achiral helical peptides.

On the other hand, little is known about effect of $N$-terminal L-residue on dominating helical screw sense in achiral peptides. Recently, ${ }^{19}$ we investigated this effect

\footnotetext{
† To whom correspondence should be addressed.
}

using Boc- $\mathrm{X}-(\mathrm{Aib}-\Delta \mathrm{Phe})_{2}-\mathrm{Aib}-\mathrm{OMe}$, in which an $\mathrm{L}-$ amino acid residue $(\mathrm{X})$ is introduced into the $N$-terminal position of achiral helical segment $-(\mathrm{Aib}-\Delta \mathrm{Phe})_{2}$ $\mathrm{Aib}-\mathrm{OMe}$ composed of $\mathrm{Aib}$ and $\triangle \mathrm{Phe}$ residues. Here $\mathrm{X}$ residue is Ala, Leu, Val, Phe, 1-naphthylalanine, and Pro. As a result, an $N$-terminal L-residue, irrespective of types of L-residues, induces a left-handed screw sense preferentially. However, systematic data on the lefthanded screw sense induced by L-residue have not been fully accumulated in terms of varying amino acid residues, chain-lengths, peptide sequences, environments (solvent and temperature), and so on.

We here focused on chain-length effect on dominating helical screw sense in peptides having only an L-Leu residue in the $N$-terminal position. For the purpose, three kinds of peptides I-III were prepared:

$$
\begin{aligned}
& \text { Boc-L-Leu -(Aib- } \Delta \text { Phe) })_{2} \text {-Aib-OMe I } \\
& \text { Boc-L-Leu -(Aib- } \Delta \text { Phe) }{ }_{3} \text {-Aib-OMe II } \\
& \text { Boc-L-Leu -(Aib- } \triangle \mathrm{Phe})_{4} \text {-Aib-OMe III }
\end{aligned}
$$

Here the repeating unit $(n)$ in achiral helical segment -(Aib- $\Delta \mathrm{Phe})_{n}-\mathrm{Aib}-\mathrm{OMe}$ increases from 2 to 4 in peptides I-III, and an L-Leu residue is introduced into the $N$-terminal positions. The conformations in solution were investigated by FT-IR, ${ }^{1} \mathrm{H}$ NMR, and CD spectroscopy. Helical screw sense was determined by sign of exciton couplets around $280 \mathrm{~nm}$ (assignable to $\triangle \mathrm{Phe}$ residue), according to exciton chirality method. ${ }^{20}$ 


\section{EXPERIMENTAL}

\section{Measurement}

${ }^{1} \mathrm{H}$ NMR spectra were recorded using a JEOL JNM-GX400 $(400 \mathrm{MHz})$, and a Hitachi R-90 spectrometer $(90 \mathrm{MHz})$. The measurements were carried out with a peptide concentration of $10-20 \mathrm{mg} \mathrm{mL}^{-1}$ in $\mathrm{CDCl}_{3}$, and a mixture of $\mathrm{CDCl}_{3} /\left(\mathrm{CD}_{3}\right)_{2} \mathrm{SO}$. All of the chemical shifts were expressed as $\delta$ downfield from tetramethylsilane (TMS). FT-IR spectra were recorded in chloroform using a JASCO FT/IR-430 spectrometer. In chloroform, peptide solution of $1-10 \mathrm{~m} M$ peptide concentration was prepared and transferred to $\mathrm{NaCl}$ cell with $0.1 \mathrm{~mm}$ cell length, and $100 \%$ chloroform was used as blank. CD and UV absorption spectra were simultaneously recorded using a JASCO J-600 spectrometer in chloroform, acetonitrile, methanol, and tetrahydrofuran (THF). These solvents were purified by distillation before use. The $\triangle$ Phe concentration was determined using maximum absorbance around $280 \mathrm{~nm}$ (assigned to a $\Delta$ Phe residue) and its molar extinction coefficient $\left(\varepsilon_{\max }=1.8 \times 10^{4}\right){ }^{21,22}$ Thin-layer chromatography (TLC) was carried out on precoated silica plates in the following solvent systems: (A) ethyl acetate, (B) methanol, (C) chloroform-methanol (9:1), and (D) $n$-butanol-acetic acid-water $(7: 2: 1)$. Gel permeation chromatography (GPC) was recorded on a Tosoh HLC803-D equipped with G5000-, G4000-, G3000-, G2000HLX columns in series, by using THF eluent. Single spot in the TLC and single peak in the GPC were obtained for all peptides I-III.

\section{Peptide Synthesis}

Boc-L-Leu-(Aib-APhe $)_{2}-A i b-O M e$ I. Boc amino acid and amino acid methyl ester were prepared by the standard procedure. Peptide I was prepared according to the previous study ${ }^{19}$ : Boc-Aib- $\Delta$ Phe azlactone was prepared via $\mathrm{Boc}-\mathrm{Aib}-\mathrm{DL}-\beta$-phenylserine- $\mathrm{OH}$, according to ref 23. Boc-Aib- $\Delta$ Phe-Aib-OMe was prepared by ringopening Boc-Aib- $\Delta$ Phe azlactone with amino group of $\mathrm{H}-\mathrm{Aib}-\mathrm{OMe}$. Likewise, Boc-(Aib- $\Delta \mathrm{Phe})_{2}-\mathrm{Aib}-\mathrm{OMe}$ was prepared by ring-opening the azlactone with $N$ deprotected $\mathrm{H}-\mathrm{Aib}-\Delta \mathrm{Phe}-\mathrm{Aib}-\mathrm{OMe}$. To obtain peptide I, Boc-L-Leu-OH was coupled with $\mathrm{H}-(\mathrm{Aib}-\Delta \mathrm{Phe})_{2}-$ Aib-OMe using dicyclohexylcarbodiimide (DCC)/1-hydroxybenzotriazole hydrate $(\mathrm{HOBt})$. The preparation and characterization of peptide $\mathbf{I}$ were described in detail previously. ${ }^{19}$

Boc- $(\mathrm{Aib}-\triangle \mathrm{Phe})_{3}-\mathrm{Aib}-\mathrm{OMe}$. Boc- $(\mathrm{Aib}-\Delta \mathrm{Phe})_{2}-\mathrm{Aib}-$ OMe $(0.80 \mathrm{~g}, 1.1 \mathrm{mmol})$ was dissolved in dichloromethane $(5 \mathrm{~mL}) /$ trifluoroacetic acid (TFA; $5 \mathrm{~mL}$ ) at $0^{\circ} \mathrm{C}$, the solution stood for $24 \mathrm{~h}$ at room temperature, and concentrated in vacuo. After addition of $5 \%$ $\mathrm{NaHCO}_{3}$ solution, the residue was extracted with ethyl acetate, the organic layer was washed with $5 \% \mathrm{NaHCO}_{3}$ and $10 \% \mathrm{NaCl}$ solutions, and dried over $\mathrm{MgSO}_{4}$. Evaporation of solvent gave white crystals of $\mathrm{H}-(\mathrm{Aib}-$ $\Delta \mathrm{Phe})_{2}$-Aib-OMe [Yield: $0.56 \mathrm{~g}(82 \%)$ ].

Boc-(Aib- $\triangle \mathrm{Phe})_{3}-\mathrm{Aib}-\mathrm{OMe}$ was prepared by ringopening Boc-Aib- $\Delta$ Phe azlactone with $\mathrm{H}-(\mathrm{Aib}-\Delta \mathrm{Phe})_{2}-$ Aib-OMe: Boc-Aib- $\Delta$ Phe azlactone $(0.57 \mathrm{~g}, 1.7 \mathrm{mmol})$ and $\mathrm{H}-(\mathrm{Aib}-\Delta \mathrm{Phe})_{2}-\mathrm{Aib}-\mathrm{OMe}(0.97 \mathrm{~g}, 1.7 \mathrm{mmol})$ were dissolved in $N, N$-dimethylformamide (DMF; $5 \mathrm{~mL}$ ), and stirred for $24 \mathrm{~h}$ at room temperature. To increase the basicity of reaction mixture, $N$-methylmorphorine (NMM; $55 \mu \mathrm{L}, 0.51 \mathrm{mmol}$ ) was added, and the reaction mixture was stirred for $36 \mathrm{~h}$ at room temperature. And then NMM $(55 \mu \mathrm{L}, 0.51 \mathrm{mmol})$ was added, the mixture was stirred for $42 \mathrm{~h}$ at room temperature, and evaporated in vacuo. The residue was extracted with ethyl acetate, the organic layer was washed with $10 \% \mathrm{NaCl}, 5 \%$ $\mathrm{KHSO}_{4}, 10 \% \mathrm{NaCl}, 5 \% \mathrm{NaHCO}_{3}$, and $10 \% \mathrm{NaCl}$ solutions, and dried over $\mathrm{MgSO}_{4}$. The product was purified by recrystallization from dichloromethane $/ n$ hexane. Yield $0.74 \mathrm{~g}(49 \%) ; \mathrm{mp} 164-166^{\circ} \mathrm{C} ; R_{\mathrm{f}}{ }^{\mathrm{A}}=0.70$ $R_{\mathrm{f}}{ }^{\mathrm{B}}=0.84 ; R_{\mathrm{f}}{ }^{\mathrm{C}}=0.53 ; R_{\mathrm{f}}{ }^{\mathrm{D}}=0.93$; retention time in GPC $\left(t_{\mathrm{R}}\right)=36.8 \mathrm{~min} .400 \mathrm{MHz}{ }^{1} \mathrm{H} \operatorname{NMR}\left(\delta\right.$, in $\left.\mathrm{CDCl}_{3}\right): 8.99$ (1H, s, NH $\Delta \mathrm{Phe}), 8.77(1 \mathrm{H}, \mathrm{s}, \mathrm{NH} \Delta \mathrm{Phe}), 8.15(1 \mathrm{H}, \mathrm{s}$, NH Aib), 8.06 (1H, s, NH Aib), 7.88 (1H, s, NH Aib), $7.79(1 \mathrm{H}, \mathrm{s}, \mathrm{NH} \Delta \mathrm{Phe}), 7.57-7.18(18 \mathrm{H}, \mathrm{m}, 3 \times$ (phenyl $\left.\left.\mathrm{H}+\mathrm{C}^{\beta} \mathrm{H}\right) \Delta \mathrm{Phe}\right), 5.18(1 \mathrm{H}, \mathrm{s}, \mathrm{NH}$ Boc-NH), $3.71(3 \mathrm{H}$, $\left.\mathrm{s}, \mathrm{COOCH}_{3}\right), 1.68+1.63+1.59+1.49+1.29(24 \mathrm{H}, \mathrm{s}+$ $\left.\mathrm{s}+\mathrm{s}+\mathrm{s}+\mathrm{s}, 8 \times \mathrm{CH}_{3} \mathrm{Aib}\right)$, and $1.44\left(9 \mathrm{H}, \mathrm{s}, 3 \times \mathrm{CH}_{3}\right.$ Boc $)$. FT-IR ( $\mathrm{cm}^{-1}$, in chloroform): $3202,1735,1699$ (shoulder), 1664, 1628, and 1534.

Boc-L-Leu-(Aib-APhe $)_{3}-A i b-O M e \quad I I . \quad$ Boc-(Aib$\triangle \mathrm{Phe})_{3}$-Aib-OMe $(0.50 \mathrm{~g}, 0.55 \mathrm{mmol})$ was dissolved in dichloromethane $(4 \mathrm{~mL}) / \mathrm{TFA}(4 \mathrm{~mL})$ at $0^{\circ} \mathrm{C}$, the solution stood for $24 \mathrm{~h}$ at room temperature, and concentrated in vacuo. After addition of $5 \% \mathrm{NaHCO}_{3}$ solution, the residue was extracted with ethyl acetate, the organic layer was washed with $5 \% \mathrm{NaHCO}_{3}$ and $10 \% \mathrm{NaCl}$ solutions, and dried over $\mathrm{MgSO}_{4}$. Evaporation of solvent gave white crystals of $\mathrm{H}-(\mathrm{Aib}-\Delta \mathrm{Phe})_{3}-\mathrm{Aib}-\mathrm{OMe}$ [Yield: $0.40 \mathrm{~g}(91 \%)]$.

To a solution of Boc-L-Leu-OH (43 mg, $0.19 \mathrm{mmol}$ ) and HOBt $(28 \mathrm{mg}, 0.19 \mathrm{mmol})$ in DMF $(0.1 \mathrm{~mL})$ was added DCC ( $38 \mathrm{mg}, 0.19 \mathrm{mmol})$ at $0^{\circ} \mathrm{C}$, and the mixture was stirred for $0.5 \mathrm{~h}$ at $0^{\circ} \mathrm{C}$. After addition of $\mathrm{H}_{-}$ (Aib- $\Delta \mathrm{Phe})_{3}-\mathrm{Aib}-\mathrm{OMe}(100 \mathrm{mg}, 0.12 \mathrm{mmol})$, the mixture was stirred for $2 \mathrm{~h}$ at $0^{\circ} \mathrm{C}$, and for $48 \mathrm{~h}$ at room temperature, concentrated in vacuo, and the residue was redissolved in ethyl acetate. After removing dicyclohexylurea by filtration, the solution was washed with $10 \%$ $\mathrm{NaCl}, 5 \% \mathrm{KHSO}_{4}, 10 \% \mathrm{NaCl}, 5 \% \mathrm{NaHCO}_{3}$, and $10 \%$ $\mathrm{NaCl}$ solutions, and dried over $\mathrm{MgSO}_{4}$. The product was purified by eluting through a silica-gel column with ethyl acetate. Yield $72 \mathrm{mg}(57 \%) ; \mathrm{mp} 243-246^{\circ} \mathrm{C} ; R_{\mathrm{f}}{ }^{\mathrm{A}}=0.67$; $R_{\mathrm{f}}{ }^{\mathrm{B}}=0.85 ; R_{\mathrm{f}}{ }^{\mathrm{C}}=0.63 ; R_{\mathrm{f}}{ }^{\mathrm{D}}=0.91 ; t_{\mathrm{R}}=36.4 \mathrm{~min} .400 \mathrm{MHz}$ ${ }^{1} \mathrm{H}$ NMR $\left(\delta\right.$, in $\left.\mathrm{CDCl}_{3}\right): 8.92(1 \mathrm{H}, \mathrm{s}, \mathrm{NH} \Delta \mathrm{Phe}), 8.78$ (1H, s, NH $\Delta \mathrm{Phe}), 8.67$ (1H, s, NH $\Delta \mathrm{Phe}), 8.14(1 \mathrm{H}, \mathrm{s}$, NH Aib), 8.05 (1H, s, NH Aib), $7.90(1 \mathrm{H}, \mathrm{s}, \mathrm{NH} \mathrm{Aib})$, $7.6-7.19\left(18 \mathrm{H}, \mathrm{m}, 3 \times\right.$ (phenyl $\left.\left.\mathrm{H}+\mathrm{C}^{\beta} \mathrm{H}\right) \Delta \mathrm{Phe}\right), 6.76$ (1H, s, NH Aib), $5.18(1 \mathrm{H}, \mathrm{d}, \mathrm{Boc}-\mathrm{NH}), 3.76-3.73(1 \mathrm{H}$, $\mathrm{m}, \mathrm{C}^{\alpha} \mathrm{H}$ Leu $), 3.75\left(3 \mathrm{H}, \mathrm{s}, \mathrm{COOCH}_{3}\right), 1.90-1.82(2 \mathrm{H}$, $\mathrm{m}, \mathrm{C}^{\beta} \mathrm{H}_{2}$ Leu $), 1.72-1.65\left(1 \mathrm{H}, \mathrm{C}^{\gamma} \mathrm{H}\right.$ Leu $), 1.63(9 \mathrm{H}, \mathrm{s}$, $3 \times \mathrm{CH}_{3}$ Boc), $1.59+1.58+1.55+1.53+1.32+1.28+$ $1.15\left(24 \mathrm{H}, \mathrm{s}+\mathrm{s}+\mathrm{s}+\mathrm{s}+\mathrm{s}+\mathrm{s}+\mathrm{s}, 8 \times \mathrm{CH}_{3} \mathrm{Aib}\right), 0.97+$ $0.93\left(6 \mathrm{H}, \mathrm{d}+\mathrm{d}, 2 \times \mathrm{CH}_{3}\right.$ Leu $)$. FT-IR $\left(\mathrm{cm}^{-1}\right.$, in chloroform): 3295, 1734, 1661, 1627, and 1535.

Boc- $(\text { Aib- } \triangle P h e)_{4}-A i b-O M e$. Boc- $(\mathrm{Aib}-\Delta \mathrm{Phe})_{4}-\mathrm{Aib}-$ $\mathrm{OMe}$ was prepared in a similar manner to Boc-(Aib- $\Delta$ Phe) $)_{3}$-Aib-OMe. Yield $77 \%$; mp 244-246 ${ }^{\circ}$; $R_{\mathrm{f}}^{\mathrm{A}}=0.62 ; \quad R_{\mathrm{f}}^{\mathrm{B}}=0.89 ; \quad R_{\mathrm{f}}{ }^{\mathrm{C}}=0.62 ; \quad R_{\mathrm{f}}^{\mathrm{D}}=0.92 ; t_{\mathrm{R}}=36.2$ $\min .400 \mathrm{MHz}{ }^{1} \mathrm{H}$ NMR $\left(\delta\right.$, in $\left.\mathrm{CDCl}_{3}\right): 9.13(1 \mathrm{H}, \mathrm{s}, \mathrm{NH}$ $\Delta \mathrm{Phe}), 9.10(1 \mathrm{H}, \mathrm{s}, \mathrm{NH} \Delta \mathrm{Phe}), 8.81$ (1H, s, NH $\Delta \mathrm{Phe})$, 
$8.23(1 \mathrm{H}, \mathrm{s}, \mathrm{NH} \Delta \mathrm{Phe}), 8.22(1 \mathrm{H}, \mathrm{s}, \mathrm{NH} \mathrm{Aib}), 8.15(1 \mathrm{H}$, s, NH Aib), 7.94 (1H, s, NH Aib), 7.92 (1H, s, NH Aib), 7.57-7.18 (24H, m, $4 \times$ (phenyl $\left.\left.\mathrm{H}+\mathrm{C}^{\beta} \mathrm{H}\right) \Delta \mathrm{Phe}\right), 5.41$ $(1 \mathrm{H}, \mathrm{s}, \mathrm{Boc}-\mathrm{NH}), 3.69\left(3 \mathrm{H}, \mathrm{s}, \mathrm{COOCH}_{3}\right), 1.73+1.63+$ $1.58+1.5-1.2\left(30 \mathrm{H}, \mathrm{s}+\mathrm{s}+\mathrm{s}+\mathrm{m}, 10 \times \mathrm{CH}_{3} \mathrm{Aib}\right)$, and $1.42\left(9 \mathrm{H}, \mathrm{s}, 3 \times \mathrm{CH}_{3}\right.$ Boc). FT-IR ( $\mathrm{cm}^{-1}$, in chloroform): 3289, 1734, 1698 (shoulder), 1660, 1626, and 1535.

Boc-L-Leu-(Aib-APhe $)_{4}-A i b-O M e$ III. Boc-L-Leu(Aib- $\Delta \mathrm{Phe})_{4}-\mathrm{Aib}-\mathrm{OMe}$ was prepared in a similar manner to Boc-L-Leu-(Aib- $\Delta \mathrm{Phe})_{3}-\mathrm{Aib}-\mathrm{OMe}$. Yield $45 \% ; \mathrm{mp} 244-246^{\circ} \mathrm{C} ; R_{\mathrm{f}}{ }^{\mathrm{A}}=0.59 ; R_{\mathrm{f}}{ }^{\mathrm{B}}=0.84 ; R_{\mathrm{f}}{ }^{\mathrm{C}}=0.57$; $R_{\mathrm{f}}{ }^{\mathrm{D}}=0.92 ; \quad t_{\mathrm{R}}=36.0 \mathrm{~min} . \quad 400 \mathrm{MHz}{ }^{1} \mathrm{H} \quad \mathrm{NMR}(\delta$, in $\left.\mathrm{CDCl}_{3}\right): 9.09(1 \mathrm{H}, \mathrm{s}, \mathrm{NH} \Delta \mathrm{Phe}), 9.02(1 \mathrm{H}, \mathrm{s}, \mathrm{NH} \Delta \mathrm{Phe})$, 8.77 (1H, s, NH $\Delta \mathrm{Phe}), 8.66(1 \mathrm{H}, \mathrm{bs}, \mathrm{NH} \Delta \mathrm{Phe}), 8.21$ (1H, s, NH Aib), 8.19 (1H, s, NH Aib), 7.99 (1H, bs, NH Aib), 7.92 (1H, s, NH Aib), 7.6-7.15 (24H, m, $4 \times\left(\right.$ phenyl $\left.\left.\mathrm{H}+\mathrm{C}^{\beta} \mathrm{H}\right) \Delta \mathrm{Phe}\right), 6.59(1 \mathrm{H}, \mathrm{s}, \mathrm{NH} \mathrm{Aib}), 4.95$ $(1 \mathrm{H}, \mathrm{s}, \mathrm{Boc}-\mathrm{NH}), 3.8-3.7\left(1 \mathrm{H}, \mathrm{m}, \mathrm{C}^{\alpha} \mathrm{H}\right.$ Leu $), 3.72(3 \mathrm{H}$, $\left.\mathrm{s}, \mathrm{COOCH}_{3}\right), 1.60\left(9 \mathrm{H}, \mathrm{s}, 3 \times \mathrm{CH}_{3} \mathrm{Boc}\right), 1.75-1.05+$ $1.26+1.17\left(33 \mathrm{H}, \mathrm{m}+\mathrm{s}+\mathrm{s}, \mathrm{C}^{\beta} \mathrm{H}_{2}-\mathrm{C}^{\gamma} \mathrm{H}\right.$ Leu and $10 \times$ $\left.\mathrm{CH}_{3} \mathrm{Aib}\right)$, and $1.0-0.8\left(6 \mathrm{H}, \mathrm{m}, 2 \times \mathrm{CH}_{3}\right.$ Leu $)$. FT-IR (cm ${ }^{-1}$, in chloroform): 3283, 1739, 1661, 1625, and 1538.

\section{Conformational Energy Calculation}

Empirical conformational energy calculations were carried out using structural and energy parameters based on ECEPP system. ${ }^{24}$ The parameters of $\triangle \mathrm{Phe}$ residue were determined in the previous study. ${ }^{21,25-28}$ The program PEPCON, ${ }^{24,29}$ written by M. Sisido ${ }^{30}$ for conformational energy calculation and graphics of a given peptide, was modified to be applicable to $\Delta \mathrm{Phe}$-containing peptides. Based on many crystallographic data of $\triangle$ Phe-containing peptides, ${ }^{4,6,7,10}$ all amide groups were fixed to the trans conformation $\left(\omega=180^{\circ}\right)$ and each $\Delta \mathrm{Phe}$ side chain $\left(\chi^{1}\right)$ was fixed to $0^{\circ}$. First, main-chain energy contour maps were calculated for $\mathrm{Ac}-(\mathrm{Aib}-\Delta \mathrm{Phe})_{n}{ }^{-}$ Aib-OMe $(n=2-4)$. Here in each $(\phi, \psi)$, the $\chi^{2}$ angle in $\triangle \mathrm{Phe}$ side chain was taken as the value that gives the minimal conformational energy.

Second, the energy minimization was carried out for Ac-L-Leu-(Aib- $\Delta$ Phe $)_{4}-\mathrm{Aib}-\mathrm{OMe}$ to predict conformations of L-Leu residue at $\mathrm{N}$-terminal position of left- or right-handed helix. The two ways were chosen. One is to energy-minimize Ac-L-Leu-(Aib- $\Delta \mathrm{Phe})_{4}-\mathrm{Aib}-\mathrm{OMe}$ with six variables of Leu residue $\left(\phi_{\text {Leu }}, \psi_{\text {Leu }}, \chi_{\text {Leu }}^{1}, \chi_{\text {Leu }}^{2}\right.$, $\left.\chi_{\text {Leu }}^{3,1}, \chi_{\text {Leu }}^{3,2}\right)$ using the Simplex algorithm, while segment -(Aib- $\Delta \mathrm{Phe})_{4}-\mathrm{Aib}-\mathrm{OMe}$ was fixed to a standard left- or

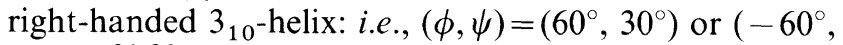
$\left.-30^{\circ}\right) .{ }^{31,32}$ Here all energy minima of L-Leu residue $(81)^{33}$ were used as starting conformations. The other is to energy-minimize $\mathrm{Ac}-\mathrm{L}-\mathrm{Leu}-(\mathrm{Aib}-\Delta \mathrm{Phe})_{4}-\mathrm{Aib}-\mathrm{OMe}$ with 36 variables of all main- and side-chains $\left(\phi_{\text {Leu }}, \psi_{\text {Leu }}\right.$, $\chi_{\text {Leu }}^{1}, \chi_{\text {Leu }}^{2}, \chi_{\text {Leu }}^{3,1}, \chi_{\text {Leu }}^{3,2}, 5 \times \phi_{\text {Aib }}, 5 \times \psi_{\text {Aib }}, 5 \times \chi_{\text {Aib }}^{1,1}, 5 \times \chi_{\text {Aib }}^{1,2}$, $\left.4 \times \phi_{\Delta \mathrm{Phe}}, 4 \times \psi_{\Delta \mathrm{Phe}}, 4 \times \chi_{\Delta \mathrm{Phe}}^{2}\right)$. Also, all energy minima of L-Leu residue (81) in a standard left- or right-handed $3_{10^{-}}$-helix, $(\phi, \psi)=\left(60^{\circ}, 30^{\circ}\right)$ or $\left(-60^{\circ},-30^{\circ}\right),{ }^{31,32}$ were used as starting conformations. The conformations of L-Leu residue were expressed by the conformational letter code that divides 16 regions in conformational space. ${ }^{33}$

\section{RESULTS AND DISCUSSION}

\section{Confirmation of Helical Conformation}

Segments -(Aib- $\Delta \mathrm{Phe})_{n}$-Aib-OMe $(n=2-4)$ can be expected to generate two "enantiomeric" (left- and right-handed) helices, since $\mathrm{Aib}$ and $\Delta \mathrm{Phe}$ residues are achiral ones and well known to be strong inducers that form a $3{ }_{10}$-helix (sometimes an $\alpha$-helix depending on peptide sequence, chain-length, or environment). Already, segment $-(\mathrm{Aib}-\Delta \mathrm{Phe})_{2}-\mathrm{OMe}$ was found to take a 3 -helix, from ${ }^{1} \mathrm{H}$ NMR spectroscopy on Boc(Aib- $\Delta \mathrm{Phe})_{2}-\mathrm{Aib}-\mathrm{OMe}{ }^{19}$ Such a helical conformation will also be expected for segments - (Aib- $\Delta \mathrm{Phe})_{n}-$ OMe ( $n=3$ and 4$)$ due to longer chain lengths. Actually, Boc-(Aib- $\Delta \mathrm{Phe})_{n}-\mathrm{Aib}-\mathrm{OMe}(n=3$ and 4$)$ showed the position of amide I band characteristic of such a $310^{-}$ type helix: 1664 and $1628 \mathrm{~cm}^{-1}$ for $n=3$, and 1660 and $1626 \mathrm{~cm}^{-1}$ for $n=4 .{ }^{34}$ Helix-forming tendency in segments $-(\mathrm{Aib}-\Delta \mathrm{Phe})_{n}-\mathrm{Aib}-\mathrm{OMe}(n=2-4)$ was also confirmed by conformational energy calculation. Figure 1 shows main-chain energy contour maps of Ac(Aib- $\Delta \mathrm{Phe})_{n}-\mathrm{Aib}-\mathrm{OMe}(n=2-4)$, indicating left- and right-handed $\left(3_{10^{-}}\right.$or $\left.\alpha^{-}\right)$helices as the most stable region.

The previous study ${ }^{19}$ indicated that peptide $\mathbf{I}$, in which an L-residue is introduced into the $N$-terminal position of segment $-(\mathrm{Aib}-\Delta \mathrm{Phe})_{2}-\mathrm{Aib}-\mathrm{OMe}$, takes a $3{ }_{10}$-type helix in chloroform. Peptides II and III should also take such a helix, based on their FT-IR spectra in chloroform $^{34}$ : 1661 and $1627 \mathrm{~cm}^{-1}$ for peptide II, and 1661 and $1625 \mathrm{~cm}^{-1}$ for peptide III. Such a helical conformation was also supported by measuring the degree of solvent exposure of each $\mathrm{NH}$ group in ${ }^{1} \mathrm{H}$ NMR spectroscopy. ${ }^{35}$ The assignment of $\mathrm{NH}$ chemical shifts in peptide $\mathbf{I}$ in $\mathrm{CDCl}_{3}$ were already done by difference Nuclear Overhauser effect spectra obtained by irradiation of each $\mathrm{NH}$ resonance. ${ }^{19,36}$ The assignment of $\mathrm{NH}$ chemical shifts in peptides II and III in $\mathrm{CDCl}_{3}$ was done with reference to that in peptide $\mathbf{I}$, since peptides II and III have analogous peptides of peptide I and were found to take a helical conformation similar to peptide I, from their FT-IR spectra in chloroform. First, the NH resonances at a higher field (ca. $5.0 \mathrm{ppm})$ in peptides I-III can be assigned to urethane $\mathrm{NH},{ }^{37-40}$ i.e., Leu(1)'s. For peptide I, the Aib(2) NH, which does not participate in intramolecular hydrogen-bonding, showed a singlet at ca. $6.6 \mathrm{ppm}$. A similar singlet for peptides II and III was seen at $c a$. $6 \mathrm{ppm}$, and thus can be assigned to $\operatorname{Aib}(2) \mathrm{NH}$, which does not participate in intramolecular hydrogen-bonding. For peptide I, two Aib NHs participating in hydrogen-bonding appeared at $c a$. $8 \mathrm{ppm}$ as a singlet. In this region ( $\mathrm{ca} .8 \mathrm{ppm})$, peptide II showed three singlets, and peptide III did four singlets, indicating that these singlets can be assigned to the remaining Aib NHs participating in hydrogen-bonding. Also peptide I showed two singlets at a lower field (ca. $8.5 \mathrm{ppm}$ ) characteristic of hydrogen-bonding $\Delta \mathrm{Phe}$ NHs. ${ }^{19,22}$ In this region (ca. $8.5-9.0 \mathrm{ppm}$ ), peptide II showed three singlets, and peptide III did four singlets, indicating that these singlets can be assigned to the hydrogen-bonding $\triangle \mathrm{Phe}$ NHs. The above assignment of hydrogen-bonding NHs in peptides II and III can be supported by the solvent dependence on $\mathrm{NH}$ chemical 
(a)

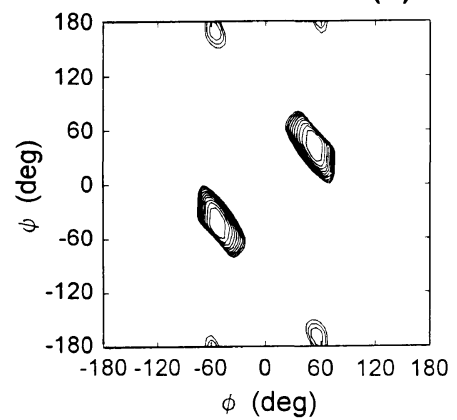

(b)

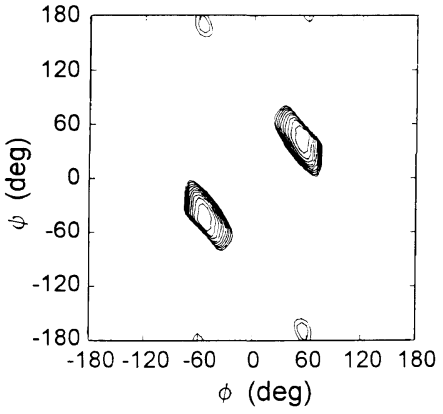

(c)

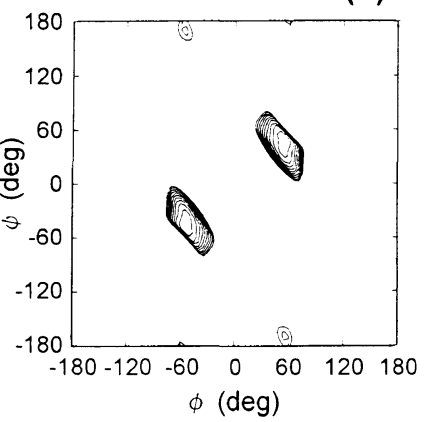

Figure 1. Main-chain energy contour map of Ac-(Aib- $\Delta \mathrm{Phe})_{n}-\mathrm{Aib}-\mathrm{OMe}$ (a) $n=2 ;$ (b) $n=3$; (c) $n=4$. The contours (10 lines) are drawn in $1.0 \mathrm{kcal}$ $[\text { mol(per residues) }]^{-1}$ increments from energy minimum points $\left(-55^{\circ},-50^{\circ}\right)$ and $\left(55^{\circ}, 50^{\circ}\right)$. In each $(\phi, \psi), \chi_{\Delta \mathrm{Phe}}^{2}$ angle(s) was taken as the value to give the minimal conformational energy, while its $\chi_{\Delta \mathrm{Phe}}^{1}$ was fixed to $0^{\circ}$.

(a)

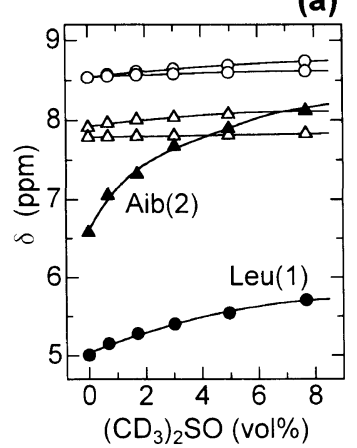

(b)

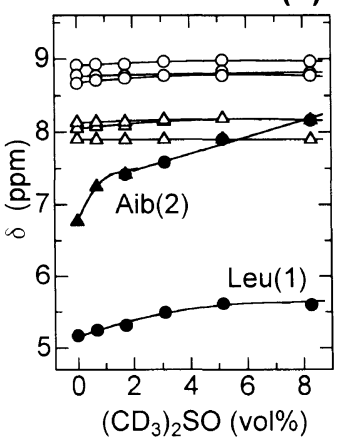

(c)

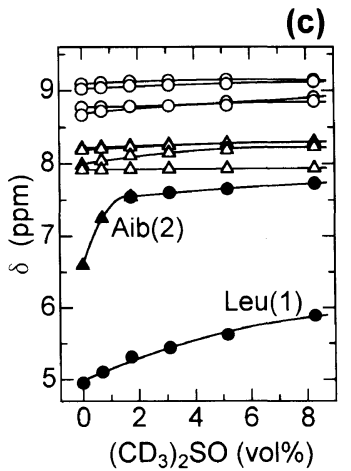

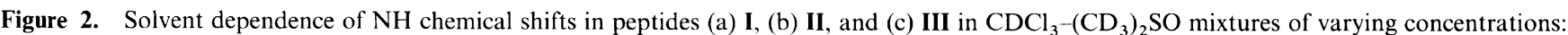
(O) for L-Leu(1), ( $\mathbf{\Delta})$ for $\mathrm{Aib}(2),(\triangle)$ for the other Aib's, and (O) for $\Delta$ Phe's.

shifts as follows.

Figure 2 shows variation in $\mathrm{NH}$ chemical shifts for peptides I-III with concentration of $\left(\mathrm{CD}_{3}\right)_{2} \mathrm{SO} .{ }^{41}$ Two $\mathrm{NH}$ resonances, Leu(1) $\mathrm{NH}$ and $\mathrm{Aib}(2) \mathrm{NH}$, were markedly shifted to a lower field with increasing concentration of $\left(\mathrm{CD}_{3}\right)_{2} \mathrm{SO}$. This means no marked conformational change, but the absence of hydrogen-bonding in Leu(1) and Aib (2) NHs, since similar sequential peptide, Boc-(L-Leu- $\Delta \mathrm{Phe})_{6}$-L-Leu-OMe, did not cause conformational change in $0-9 \mathrm{vol} \%\left(\mathrm{CD}_{3}\right)_{2} \mathrm{SO}^{22}$ Also, similar results were obtained in dependence of $\mathrm{NH}$ resonance line widths in peptide I-III on the addition of $2,2,6,6$,-tetramethylpiperidine (TEMPO) ${ }^{42}$ in $\mathrm{CDCl}_{3}$. There was remarkably pronounced line broadening of Leu(1) NH and Aib(2) NH resonances, while the other NHs remain almost unaffected. These NMR results indicate that the NHs except for Leu(1) NH and Aib(2) NH were relatively unaffected by the addition of strong hydrogen-accepting $\left(\mathrm{CD}_{3}\right)_{2} \mathrm{SO}$ or paramagnetic TEMPO, and thus should be shielded from solvent due to intramolecular hydrogen-bonding. ${ }^{41,42}$ This hydrogenbonding pattern corresponds to $3_{10}$-type helical $[4 \rightarrow 1$ hydrogen-bonding] mode, ${ }^{21,22}$ in which all the NHs except for Leu(1) $\mathrm{NH}$ and Aib(2) $\mathrm{NH}$ participate in intramolecular hydrogen bonding. Consequently, helical conformations were retained by the introduction of an L-Leu residue into the $N$-terminal position of helical segment $-(\mathrm{Aib}-\Delta \mathrm{Phe})_{n}-\mathrm{Aib}-\mathrm{OMe}(n=2-4)$.

\section{Determination of Helical Screw Sense}

As expected, peptides Boc-(Aib- $\Delta \mathrm{Phe})_{n}-\mathrm{Aib}-\mathrm{OMe}$ $(n=2-4)$ showed no CD signals due to no chiral residues

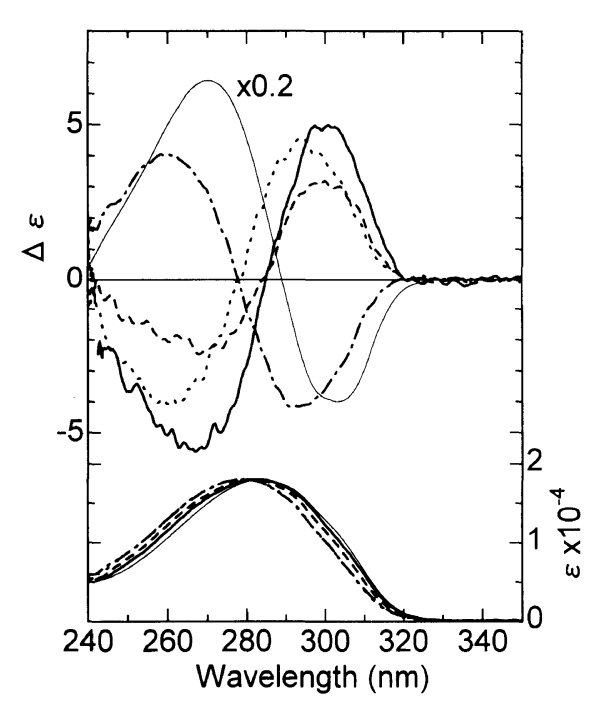

Figure 3. CD (top) and UV absorption (bottom) spectra of peptides

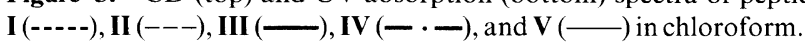

being included, indicating they take left- and righthanded helices with the same contents. On the other hand, marked CD signals were observed for peptides I-III, in which an L-Leu residue is attached to the $N$-terminal position of enantiomeric helical segment -(Aib-APhe $)_{n}-\mathrm{Aib}-\mathrm{OMe}$. Figure 3 shows CD and UV absorption spectra of peptides I-III in chloroform. The $\Delta \varepsilon\left(=\varepsilon_{\mathrm{L}}-\varepsilon_{\mathrm{R}}\right)$ is expressed with respect to the molar concentration of $\Delta \mathrm{Phe}$ residue.

All UV absorption spectra showed intense maxima $\left(\lambda_{\max }\right)$ around $280 \mathrm{~nm}$ (band I) assignable to $\Delta \mathrm{Phe}$ residue. 
Table I. Spectroscopic properties of peptides $\mathbf{I}-\mathbf{V}$ in solution

\begin{tabular}{|c|c|c|c|c|c|}
\hline \multirow{2}{*}{ Peptide } & \multirow{2}{*}{ Solvent } & \multirow{2}{*}{$\frac{\text { UV Data }}{\lambda_{\max } / \mathrm{nm}}$} & \multicolumn{3}{|c|}{ CD Data } \\
\hline & & & $\Delta \varepsilon_{\max } / \lambda_{\max } / \mathrm{nm}$ & $\Delta \varepsilon_{\min } / \lambda_{\min } / \mathrm{nm}$ & $A$ \\
\hline $\mathbf{I}^{\mathrm{a}}$ & Chloroform & 280 & $4.6 / 294$ & $-4.1 / 260$ & 8.7 \\
\hline II & Chloroform & 281 & $3.2 / 300$ & $-2.5 / 268$ & 5.7 \\
\hline III & Chloroform & 282 & $5.0 / 300$ & $-5.6 / 267$ & 10.6 \\
\hline $\mathbf{I} \mathbf{V}^{\mathrm{a}}$ & Chloroform & 280 & $4.2 / 260$ & $-4.2 / 292$ & 8.4 \\
\hline $\mathbf{V}$ & Chloroform & 284 & $31.5 / 270$ & $-19.5 / 303$ & 51.0 \\
\hline $\mathbf{I}^{\mathrm{a}}$ & Acetonitrile & 280 & $6.3 / 296$ & $-6.8 / 262$ & 13.1 \\
\hline II & Acetonitrile & 280 & $7.9 / 298$ & $-10.0 / 266$ & 17.9 \\
\hline III & Acetonitrile & 281 & $9.2 / 298$ & $-11.1 / 265$ & 20.3 \\
\hline $\mathbf{I} \mathbf{V}^{\mathrm{a}}$ & Acetonitrile & 280 & $7.0 / 260$ & $-6.2 / 295$ & 13.2 \\
\hline $\mathbf{V}$ & Acetonitrile & 281 & $20.6 / 270$ & $-10.8 / 295$ & 31.4 \\
\hline $\mathbf{I}^{\mathrm{a}}$ & Methanol & 282 & $7.5 / 297$ & $-7.9 / 264$ & 15.4 \\
\hline II & Methanol & 280 & $6.8 / 298$ & $-9.2 / 267$ & 16.0 \\
\hline III & Methanol & 282 & $7.7 / 299$ & $-9.1 / 267$ & 16.8 \\
\hline $\mathbf{I V} \mathbf{V}^{\mathrm{a}}$ & Methanol & 281 & $8.1 / 263$ & $-7.8 / 295$ & 15.9 \\
\hline $\mathbf{V}$ & Methanol & 281 & $16.2 / 270$ & $-7.0 / 303$ & 23.2 \\
\hline $\mathbf{I}^{\mathrm{a}}$ & THF & 277 & $9.8 / 292$ & $-10.9 / 258$ & 20.7 \\
\hline II & THF & 280 & $11.2 / 298$ & $-12.3 / 266$ & 23.5 \\
\hline III & THF & 280 & $14.6 / 299$ & $-16.5 / 265$ & 31.1 \\
\hline $\mathbf{I V}$ & THF & 276 & $11.1 / 258$ & $-9.4 / 291$ & 20.5 \\
\hline $\mathbf{V}$ & THF & 281 & $24.2 / 268$ & $-15.6 / 303$ & 39.8 \\
\hline
\end{tabular}

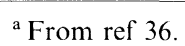

The UV pattern did not change in all peptides I-III, but resembled that of Boc-L-Leu- $\Delta$ Phe-L-Leu-OMe ${ }^{22}$ having a single $\Delta$ Phe residue. Thus, no strong groundstate interaction between $\Delta \mathrm{Phe}-\Delta \mathrm{Phe}$ pair(s) exists in peptides I-III. Such interaction was also not observed in $3{ }_{10}$-helical peptides containing $\Delta$ Phe residues. ${ }^{21,22,27}$

The corresponding CD spectra of peptides I-III showed marked exciton couplets around $280 \mathrm{~nm}$ with a positive peak at longer wavelengths, as shown in Figure 3 . Peptides containing $\triangle$ Phe residues show intense absorption maxima around $220 \mathrm{~nm}$ and around $280 \mathrm{~nm}$ (band I). ${ }^{13,21}$ The former absorption band precludes a far-UV CD analysis to usually investigate conformations of peptides or proteins. On the other hand, the latter absorption band has been assigned to charge transfer from the highest occupied orbital localized on styryl moiety to the vacant orbital of carbonyl group in $\Delta$ Phe residue. ${ }^{43,44}$ The transition moment was estimated from molecular orbital calculation to lie on the styryl-carbonyl line. ${ }^{21}$ By applying the exciton chirality method ${ }^{20}$ to the present system, the sign of split CD pattern corresponds to a left-handed helical arrangement of the transition moment, meaning left-handed helical main chain. This assignment has also been used for $3_{10}$-helical peptides containing $\Delta \mathrm{Phe}-\mathrm{X}-\Delta \mathrm{Phe}$ unit $(\mathrm{s})^{1,2,5,13,22,27}$ : i.e., the sign of exciton couplets at band $I$ is a positive peak at longer wavelengths for a left-handed helix and a negative peak at longer wavelengths for a right-handed helix. Moreover, the sign of exciton couplets observed here (a positive peak at longer wavelengths) should be ascribed to left-handed $310^{-}$or $\alpha$-helices, based on theoretical CD calculation. ${ }^{21,25}$ Namely, exciton couplets with a positive peak at longer wavelengths were obtained at band I for Boc-(Aib- $\Delta \mathrm{Phe})_{n}-\mathrm{Aib}-\mathrm{OMe}(n=2-4)$ in five lefthanded $3_{10}$-type ( $4 \rightarrow 1$ hydrogen bonded) helices (1)-(5) and in three left-handed $\alpha$-type $(5 \rightarrow 1$ hydrogen bonded) helices (6)-(8): (1) $\phi=44^{\circ}, \psi=33^{\circ}$; (2) $\phi=54^{\circ}, \psi=28^{\circ}$; (3) $\phi=71^{\circ}, \psi=18^{\circ}$; (4) $\phi=53^{\circ}, \psi=36^{\circ}$; (5) $\phi=60^{\circ}$, $\psi=30^{\circ}$; (6) $\phi=53^{\circ}, \psi=52^{\circ}$; (7) $\phi=57^{\circ}, \psi=47^{\circ}$; (8) $\phi=63^{\circ}, \psi=42^{\circ}$. These eight left-handed helices $(\phi, \psi)$ correspond to the right-handed ones $(-\phi,-\psi)$ reported. $45-48,31,32,49-51$ Therefore, the main chains of peptides I-III prefer the left-handed screw sense to the right-handed one. Obviously, the preference of lefthanded screw sense by an $N$-terminal L-residue is retained, irrespective of chain-lengths of achiral helical segments (5-9 residues). On the other hand, peptide Boc-D-Leu-(Aib- $\Delta$ Phe) ${ }_{2}-\mathrm{Aib}-\mathrm{OMe}$ (IV) containing a D-Leu residue in the $N$-terminal position gave almost completely asymmetric CD spectrum, compared with peptide I containing an L-Leu residue in the $N$-terminal position: i.e., peptide IV showed marked exciton couplets with a negative peak at longer wavelengths and gave the split amplitude value similar to peptide $\mathbf{I}$, as shown in Figure 3 and Table I.

Figures 4-6 show CD and UV absorption spectra of peptides I-III in acetonitrile, methanol, and THF, respectively. In these solvents, $\mathrm{CD}$ patterns at band I were similar to those in chloroform. It should also be concluded that an $N$-terminal L-Leu residue induces a left-handed screw sense preferentially. Here the split amplitude $(A)^{21,25}$ is defined as the difference between the maximum and minimum $\Delta \varepsilon\left(\Delta \varepsilon_{\max }\right.$ and $\left.\Delta \varepsilon_{\min }\right)$ values in the couplets of band I. In all solvents, peptide III showed the largest $A$ value, since it might have the strongest dipole-dipole interaction due to the longest chain. On the other hand, peptide III showed smaller $A$ values in all solvents than Boc-(L-Leu- $\Delta \mathrm{Phe})_{4}-\mathrm{L}-$ Leu-OMe $(\mathbf{V})$ that takes a right-handed $3{ }_{10}$-type helical conformation in chloroform, ${ }^{22,27}$ as shown in Figures $3-6$ and Table I. Peptide $\mathbf{V}$ is regarded as analogous peptide of Boc- $(\mathrm{Aib}-\Delta \mathrm{Phe})_{4}-\mathrm{Aib}-\mathrm{OMe}$ in which all $\mathrm{Aib}$ 


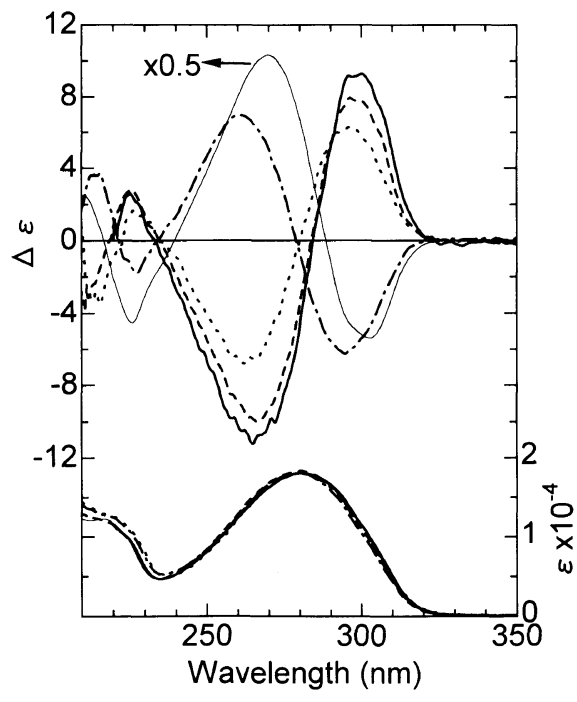

Figure 4. $\mathrm{CD}$ (top) and UV absorption (bottom) spectra of peptides I (----), II (---), III (-), IV (-•- ) , and V (- - in acetonitrile.

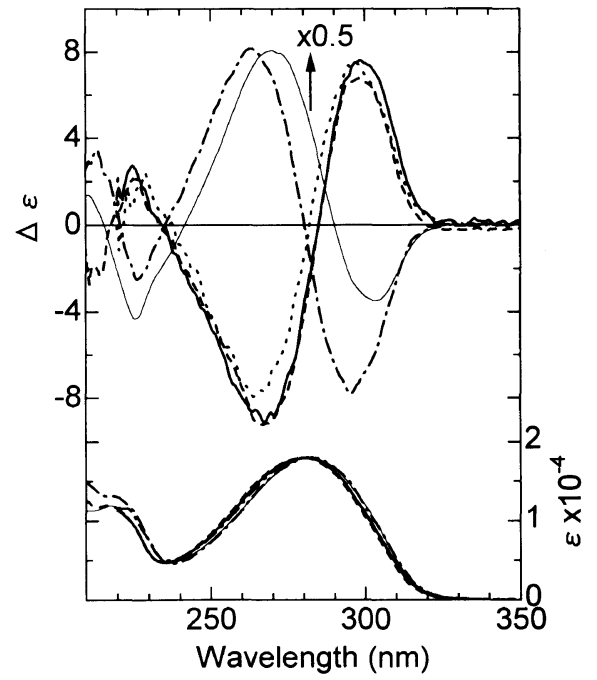

Figure 5. CD (top) and UV absorption (bottom) spectra of peptides I (----), II (---), III (-), IV (- - - ) , and V (- - in acetonitrile.

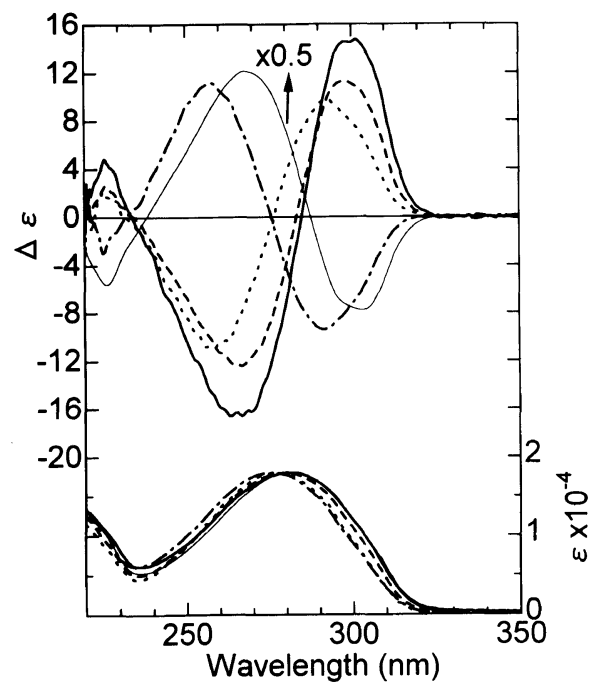

Figure 6. $\mathrm{CD}$ (top) and UV absorption (bottom) spectra of peptides I (-.-), II (--), III (-), IV (-・-), and V $(\square)$ in THF.
Table II. Energy-minimized conformations for L-Leu residue in Ac-L-Leu-(Aib- $\Delta \mathrm{Phe})_{4}-\mathrm{Aib}-\mathrm{OMe}$ in a standard $3_{10}$-helix $^{\mathrm{a}}$

\begin{tabular}{|c|c|c|c|c|}
\hline \multirow{2}{*}{$\begin{array}{l}\text { Conformational } \\
\text { letter code } \mathrm{c}^{\mathrm{b}}\end{array}$} & \multicolumn{2}{|c|}{ Leu } & \multirow{2}{*}{$\begin{array}{l}\text { Helical } \\
\text { screw } \\
\text { sense }^{\mathfrak{c}}\end{array}$} & \multirow{2}{*}{$\frac{\Delta E_{\mathrm{res}}^{\mathrm{d}}}{\mathrm{kcal} \mathrm{mol}^{-}}$} \\
\hline & $\phi$ & $\psi$ & & \\
\hline $\mathrm{C}$ & -64 & 115 & LH & - \\
\hline A & -65 & -53 & RH & 0.09 \\
\hline $\mathrm{A}^{*}$ & 56 & 70 & LH & 0.15 \\
\hline $\mathrm{C}$ & -78 & 101 & $\mathrm{RH}$ & 0.16 \\
\hline $\mathrm{C}$ & -66 & 120 & LH & 0.17 \\
\hline $\mathrm{A}^{*}$ & 56 & 67 & LH & 0.22 \\
\hline $\mathrm{C}$ & -81 & 83 & LH & 0.23 \\
\hline A & -70 & -52 & LH & 0.24 \\
\hline D & -148 & 103 & RH & 0.25 \\
\hline $\mathrm{F}$ & -63 & 134 & LH & 0.25 \\
\hline
\end{tabular}

${ }^{\text {a }}$ Energy-minimization was carried out for six variables of L-Leu residue $\left(\phi_{\text {Leu }}, \quad \psi_{\text {Leu }}, \chi_{\text {Leu }}^{1}, \chi_{\text {Leu }}^{2}, \quad \chi_{\text {Leu }}^{3,1}, \chi_{\text {Leu }}^{3,2}\right)$, while the segment -(Aib- $\triangle \mathrm{Phe})_{4}-\mathrm{Aib}-\mathrm{OMe}$ is fixed to a standard left- or right-handed $3_{10}$-helix: $\left(60^{\circ}, 30^{\circ}\right)$ or $\left(-60^{\circ},-30^{\circ}\right),{ }^{31,32}$ respectively. ${ }^{\mathrm{b}}$ For Leu residue. ${ }^{\mathrm{c}} \mathrm{LH}$ and $\mathrm{RH}$ represent left- and right-handed helical screw senses for segment $-(\mathrm{Aib}-\Delta \mathrm{Phe})_{4}-\mathrm{Aib}-\mathrm{OMe}$, respectively. ${ }^{\mathrm{d}} \Delta E_{\mathrm{res}}=$ $\left(E-E_{0}\right) / 10 . E_{0}$ is the lowest energy.

residues are replaced by L-Leu residue. Assuming that the $A$ values of peptide $\mathbf{V}$ correspond to those for $100 \%$ right-handed helical conformation, smaller $A$ value of peptide III than peptide $\mathbf{V}$ should mean that peptide III contains not only a left-handed helix, but a right-handed one in an equilibrium state. Particularly in chloroform in which both peptides III and $\mathbf{V}$ take a $3_{10}$-type helical conformation, peptide III was estimated to contain $60 \%$ left-handed helix and $40 \%$ right-handed one, based on an $A$ value of 10.6 for peptide III and 51.0 for peptide $\mathbf{V}$ in Table I. From the similar calculation, peptide III was also estimated to contain $82 \%$ left-handed helix in chloroform, $86 \%$ left-handed helix in methanol, and $89 \%$ left-handed helix in THF. In the three solvents, a lefthanded helix in peptide III was taken more preferentially. For peptides I and II, such estimation could not be done due to lack of appropriate model peptides showing almost $100 \%$ right- or left-handed helical conformation: e.g., Boc-(L-Leu- $\Delta \mathrm{Phe})_{2}-\mathrm{L}-\mathrm{Leu}-\mathrm{OMe}$ for peptide I showed solvent dependence on CD patterns, and Boc- $(\mathrm{L}-$ Leu- $\Delta \mathrm{Phe})_{3}-\mathrm{L}$-Leu-OMe for peptide II showed exciton couplets at a negative peak at longer wavelengths, but somewhat distorted splitting patterns. ${ }^{22}$

\section{Conformation of N-Terminal L-Leu Residue in Left- Handed Helix}

In the preceding section, it should be concluded that an $N$-terminal L-Leu residue induces a left-handed screw sense preferentially. Table II shows energy-minimized conformations of $\mathrm{L}-\mathrm{Leu}$ residue in Ac-L-Leu-(Aib$\Delta \mathrm{Phe})_{4}-\mathrm{Aib}-\mathrm{OMe}$, in which segment $-(\mathrm{Aib}-\Delta \mathrm{Phe})_{4}-$ Aib-OMe is fixed to a standard left- or right-handed $3_{10}$-helix, ${ }^{31,32}$ and lists from the lowest-energy to tenth low-energy conformations. $\Delta E_{\mathrm{res}}$ is the energy difference per residue from the lowest energy. In Table II, the left-handed helix was found as the lowest-energy conformation, and seven left-handed helices were present among ten conformers $\left(\Delta E_{\mathrm{res}} \leqq 0.25 \mathrm{kcal} \mathrm{mol}^{-1}\right)$, thus indicating that the left-handed helix is predominant. This prediction agreed well with the preceding experimental results. In the lowest-energy right-handed helix (second 
low-energy conformation in Table II), $N$-terminal L-Leu residue showed a conformational letter code of "A", 33 which corresponds to a region for a right-handed $3_{10^{-}}$or $\alpha$-helical conformation. Namely, an $N$-terminal L-Leu residue is incorporated into a right-handed helical conformation of $-(\mathrm{Aib}-\Delta \mathrm{Phe})_{4}-\mathrm{Aib}-\mathrm{OMe}$. On the other hand, interestingly, an $N$-terminal L-Leu residue in the lowest-energy left-handed helix took a conformational letter code of "C", but not of "A*", ${ }^{33}$ which corresponds to a region for left-handed $3_{10^{-}}$or $\alpha$-helical conformation. It should be noted that an $N$-terminal L-Leu residue is not incorporated into a left-handed helical conformation $\left(\mathrm{A}^{*}\right)$, but takes an irregular conformation that deviates from a left-handed helix.

Table III shows energy-minimized conformations of Ac-L-Leu-(Aib- $\Delta$ Phe) ${ }_{4}-\mathrm{Aib}-\mathrm{OMe}$. Unlike in Table II, a right-handed helix was found as the lowest-energy conformation. However, the energy difference between the lowest-energy left- and right-handed helices was very small $\left(\Delta E_{\mathrm{res}}=0.06 \mathrm{kcal} \mathrm{mol}^{-1}\right)$, and seven left-handed helices were present among ten conformers $\left(\Delta E_{\text {res }} \leqq\right.$ $0.23 \mathrm{kcal} \mathrm{mol}^{-1}$ ), thus indicating that a left-handed helix is also predominant. The energy-minimized conformations $(\langle\phi\rangle$ and $\langle\psi\rangle)$ for segment $-(\mathrm{Aib}-\Delta \mathrm{Phe})_{4}-\mathrm{Aib}-$ OMe appear to have a character of $310^{-}$and $\alpha$-type helices in the hydrogen-bonding mode, irrespective of conformations of Leu residue and of helical screw sense. This energy-minimized helix differed somewhat from a $3_{10}$-helix obtained in the preceding ${ }^{1} \mathrm{H}$ NMR study. On the other hand, $310^{-}$and $\alpha$-helices take similar conformations: e.g., $(\phi, \psi)$ is $\left(-60^{\circ},-30^{\circ}\right)^{31,32}$ for standard $310^{- \text {helix, and }}\left(-57^{\circ},-47^{\circ}\right)^{50}$ for standard $\alpha$ helix. Also, the energy difference between both helices should be small, since $3_{10^{-}}$to $\alpha$-helical transitions occur with solvents and chain-lengths in Aib-containing peptides. ${ }^{14,52-59}$ Thus, it seems difficult to predict both helical structures. However, the conformations of $\mathrm{N}$ terminal L-Leu residue showed the tendency similar to those in Table II: i.e., a conformational letter code of " $A$ " for the lowest-energy right-handed helix, and of " $C$ ", for the lowest-energy left-handed helix (second lowenergy conformation in Table III).

To obtain further information, main-chain contour map of L-Leu residues was calculated on Ac- $\mathrm{L}-$ Leu-(Aib- $\Delta \mathrm{Phe})_{4}-\mathrm{Aib}-\mathrm{OMe}$. Here the segment - (Aib$\Delta \mathrm{Phe})_{4}-\mathrm{Aib}-\mathrm{OMe}$ was fixed to a standard $310^{- \text {helix }}$ $\left(-60^{\circ},-30^{\circ}\right)^{31,32}$ based on ${ }^{1} \mathrm{H}$ NMR results, and side

Table III. Energy-minimized conformations of $\mathrm{Ac}-\mathrm{L}-\mathrm{Leu}-(\mathrm{Aib}-\Delta \mathrm{Phe})_{4}-\mathrm{Aib}-\mathrm{OMe}^{\mathrm{a}}$

\begin{tabular}{|c|c|c|c|c|c|c|}
\hline \multirow{2}{*}{$\begin{array}{l}\text { Conformational } \\
\text { letter code }\end{array}$} & \multicolumn{2}{|c|}{ Leu } & \multirow{2}{*}{$\begin{array}{c}\text { Helical } \\
\text { screw } \\
\text { sense }^{\mathrm{c}}\end{array}$} & \multicolumn{2}{|c|}{$\mathrm{Aib} \cdot \Delta \mathrm{Phe}^{\mathrm{d}}$} & \multirow{2}{*}{$\frac{\Delta E_{\mathrm{res}}^{\mathrm{e}}}{\mathrm{kcal} \mathrm{mol}^{-1}}$} \\
\hline & $\phi$ & $\psi$ & & $\langle\phi\rangle$ & $\langle\psi\rangle$ & \\
\hline A & -63 & -57 & $\mathrm{RH}$ & -54 & -48 & - \\
\hline $\mathrm{C}$ & -65 & 109 & LH & 54 & 47 & 0.06 \\
\hline A & -65 & -57 & $\mathrm{RH}$ & -56 & -47 & 0.06 \\
\hline$A^{*}$ & 56 & 64 & $\mathrm{LH}$ & 54 & 49 & 0.07 \\
\hline $\mathrm{C}$ & -73 & 98 & $\mathrm{LH}$ & 54 & 49 & 0.09 \\
\hline $\mathrm{C}$ & -66 & 109 & $\mathrm{LH}$ & 54 & 49 & 0.13 \\
\hline$A^{*}$ & 55 & 54 & $\mathrm{LH}$ & 53 & 49 & 0.14 \\
\hline$A^{*}$ & 57 & 67 & $\mathrm{LH}$ & 54 & 46 & 0.15 \\
\hline $\mathrm{C}$ & -75 & 97 & $\mathrm{LH}$ & 54 & 49 & 0.21 \\
\hline $\mathrm{E}$ & -147 & 127 & $\mathrm{RH}$ & -52 & -52 & 0.23 \\
\hline
\end{tabular}

${ }^{a}$ Energy-minimization was carried out for 36 variables of all main- and side-chains. ${ }^{b}$ For Leu residue. ${ }^{\mathrm{c}} \mathrm{LH}$ and $\mathrm{RH}$ represent left- and right-handed helical screw senses for segment (Aib- $\Delta$ Phe $)_{4}$ - Aib OMe, respectively. ${ }^{\mathrm{d}}\langle\phi\rangle$ and $\langle\psi\rangle$ values were averaged for five Aib and four $\Delta \mathrm{Phe}$ residues in segment $-(\mathrm{Aib}-\Delta \mathrm{Phe})_{4}-\mathrm{Aib}-$ OMe. ${ }^{\mathrm{e}} \Delta E_{\mathrm{res}}=\left(E-E_{0}\right) / 10 . E_{0}$ is the lowest energy.

\section{(b)}

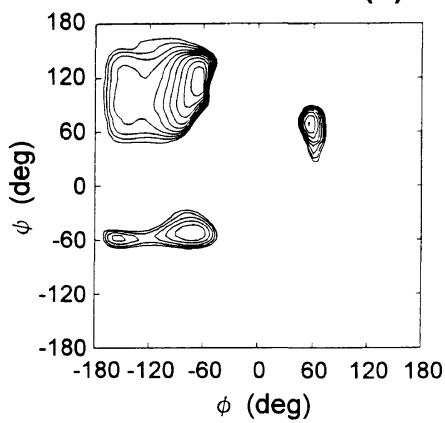

(c)

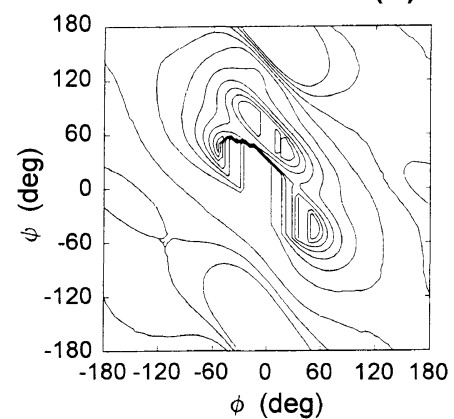

(d)

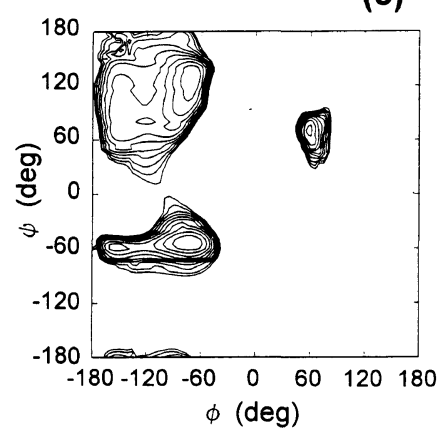

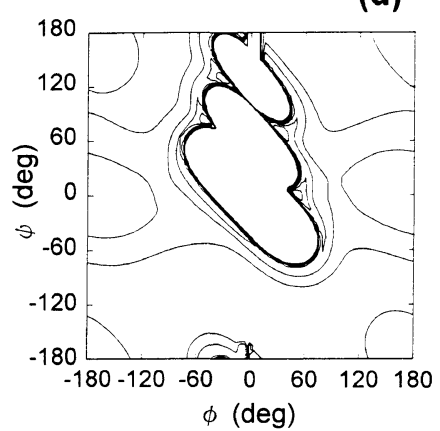

Figure 7. Main-chain energy contour map of L-Leu residue on Ac-L-Leu-(Aib- $\Delta \mathrm{Phe})_{4}-\mathrm{Aib}-\mathrm{OMe}$ in terms of (a) total energy, (b) electrostatic energy, (c) nonbonded energy, and (d) hydrogen-bond energy. The contours ( 10 lines) are drawn in $0.5 \mathrm{kcal} \mathrm{mol}^{-1}$ increments from energy minimum points of (a) $\left(-65^{\circ}, 115^{\circ}\right)$, (b) $\left(55^{\circ},-45^{\circ}\right)$, (c) $\left(-70^{\circ},-55^{\circ}\right)$, and (d) $\left(55^{\circ}, 0^{\circ}\right)$. The segment $-(\text { Aib }-\Delta \mathrm{Phe})_{4}-\mathrm{Aib}-\mathrm{OMe}$ was fixed to a standard $3_{10}$-helix $\left(-60^{\circ},-30^{\circ}\right)^{31,32}$ based on ${ }^{1} \mathrm{H}$ NMR results, and side chain of L-Leu $\left(\chi^{1}, \chi^{2}\right)$ in each $(\phi, \psi)$ was taken as the value giving the minimal conformational energy when $\chi^{1}$ and $\chi^{2}$ angles were changed from $0^{\circ}$ to $350^{\circ}$ at $10^{\circ}$. 
chain of L-Leu $\left(\chi^{1}, \chi^{2}\right)$ in each $(\phi, \psi)$ was taken as the value that gives the minimal conformational energy when $\chi^{1}$ and $\chi^{2}$ angles were changed from $0^{\circ}$ to $350^{\circ}$ at $10^{\circ}$. As shown in Figure 7 (a), $\left(-65^{\circ}, 115^{\circ}\right)$ was found as the minimum energy point, corresponding to that in Table II. Figures 7 (b) - (d) show the corresponding contour maps in terms of electrostatic energy, nonbonded energy, and hydrogen-bond energy, respectively. The map of total energy (Figure 7(a)) was similar to that of nonbonded energy (Figure 7(c)) in the pattern. Thus, nonbonded energy term is mainly ascribed to that the $N$ terminal L-Leu residue in the lowest-energy $3_{10}$-helix takes a conformation deviating from the left-handed helix $\left(A^{*}\right)$.

\section{CONCLUSIONS}

In the present paper, we focused on which helical screw sense is dominated depending on chain lengths when an L-Leu residue is introduced into the $N$-terminal position of achiral helical segments. First, an $N$-terminal L-Leu residue induces a left-handed screw sense preferentially, irrespective of chain lengths of achiral helical segments (5-9 residues). Second, in the lowest-energy left-handed helical conformation, an $N$-terminal L-Leu residue takes an irregular conformation that deviates from a left-handed $30_{10} / \alpha$-helical region in conformational space of $(\phi, \psi)$ (a conformational letter code of "A*").

Acknowledgments. We express our sincere gratitude to Professor M. Kawai in Department of Applied Chemistry, Nagoya Institute of Technology for the use of $\mathrm{CD}$ apparatus.

\section{REFERENCES}

1. R. Jain and V. S. Chauhan, Biopolymers (Peptide Science), 40, 105 (1996).

2. O. Pieroni, A. Fissi, R. M. Jain, and V. S. Chauhan, Biopolymers, 38, 97 (1996).

3. S. N. Mitra, S. Dey, S. Karthikeyan, and T. P. Singth, Biopolymers, 41, 97 (1997).

4. K. R. Rajashankar, S. Ramakumar, and V. S. Chauhan, J. Am. Chem. Soc., 114, 9225 (1992).

5. O. Pieroni, A. Fissi, C. Pratesi, P. A. Temussi, and F. Ciardelli, J. Am. Chem. Soc., 113, 6338 (1991).

6. M. R. Ciajolo, A. Tuzi, C. R. Pratesi, A. Fissi, and O. Pieroni, Biopolymers, 30, 911 (1990).

7. K. K. Bhandary and V. S. Chauhan, Biopolymers, 33, 209 (1993).

8. B. Padmanbhan and T. P. Singh, Biopolymers, 33, 613 (1993).

9. V. S. Chauhan, K. Uma, P. Kaur, and P. Balaram, Biopolymers, 28, 763 (1989).

10. M. R. Ciajoro, A. Tuzi, C. R. Pratesi, A. Fissi, and O. Pieroni, Biopolymers, 32, 717 (1992).

11. A. Gupta, A. Bharadwaj, and V. S. Chauhan, J. Chem. Soc., Perkin Trans 2, 1991 (1990).

12. A. Tuzi, M. R. Ciajoro, G. Guarino, P. A. Temussi, A. Fissi, and O. Pienori, Biopolymers, 33, 1111 (1993).

13. O. Pieroni, A. Fissi, C. Pratesi, P. A. Temussi, and F. Ciardelli, Biopolymers, 33, 1 (1993).

14. K. Uma and P. Balaram, Indian J. Chem., 28B, 705 (1989), and references therein.

15. B. V. V. Prasad and P. Balaram, CRC. Crit. Rev. Biochem., 16, 307 (1984)

16. R. Bosch, G. Jung, H. Schmitt, G. M. Sheldrick, and W. Winter, Angew. Chem. Int. Ed. Engl., 23, 450 (1984).

17. E. Benedetti, A. Bavoso, B. Di Blasio, V. Pavone, C. Pedone, C.
Toniolo, and G. M. Bonora, Proc. Natl. Acad. Sci. U.S.A., 79 7951 (1982)

18. T. S. Cameron, A. W. Hanson, and A. Taylor, Cryst. Struct. Commun., 11, 321 (1982).

19. Y. Inai, Y. Kurokawa, A. Ida, and T. Hirabayashi, Bull. Chem Soc. Jpn., 72, 55 (1999)

20. N. Harada, S. L. Chen, and K. Nakanishi, J. Am. Chem. Soc. 97, 5345 (1975)

21. Y. Inai, T. Ito, T. Hirabayashi, and K. Yokota, Biopolymers, 33, 1173 (1993).

22. Y. Inai, K. Hasegawa, T. Hirabayashi, and K. Yokota, Polym. J., 28, 238 (1996)

23. D. G. Doherty, J. E. Tietzman, and M. Bergmann, J. Biol. Chem., 147, 617 (1943)

24. F. Momany, R. F. McGuire, A. W. Burgess, and H. A. Scheraga, J. Phys. Chem., 79, 2361 (1975).

25. Y. Inai, T. Ito, T. Hirabayashi, and K. Yokota, Polym. J., 27, 846 (1995).

26. Y. Inai, S. Kurashima, Y. Okado, T. Hirabayashi, and K. Yokota, Bull. Chem. Soc. Jpn., 69, 1687 (1996).

27. Y. Inai, K. Hasegawa, T. Hirabayashi, and K. Yokota, Polym. J., 28, 440 (1996).

28. Y. Inai, Y. Sakakura, and T. Hirabayashi, Polym. J., 29, 649 (1997).

29. Y. Beppu, Comput. Chem., 13, 101 (1989)

30. M. Sisido, private communications.

31. Y. Paterson, S. M. Rumsey, E. Benedetti, G. Nemethy, and H. A. Scheraga, J. Am. Chem. Soc., 103, 2947 (1981)

32. G. N. Ramachandran and V. Sasisekharan, Adv. Protein Chem., 23, 238 (1968).

33. S. S. Zimmerman, M. S. Pottle, G. Nemethy, and H. A. Scheraga, Macromolecules, 10, 1 (1977).

34. Y. Inai, Y. Sakakura, and T. Hirabayashi, Polym. J., 30, 828 (1998).

35. J. A. Smith and L. G. Pease, CRC Crit Rev. Biochem., 8, 315 (1980).

36. Y. Inai, Y. Kurokawa, and T. Hirabayashi, Biopolymers, in press.

37. M. Iqbal and P. Balaram, Biochemistry, 20, 4866 (1981).

38. R. Nagaraj, N. Shamala, and P. Balaram, J. Am. Chem. Soc., 95, 1399 (1979).

39. R. Nagaraj and P. Balaram, Biochemistry, 20, 2828 (1981).

40. M. Iqbal and P. Balaram, J. Am. Chem. Soc., 103, 5548 (1981).

41. T. P. Pitnter and D. W. Urry, J. Am. Chem. Soc., 94, 1399 (1972).

42. K. D. Kopple, A. Go, and P. R. Pilipauskas, J. Am. Chem. Soc., 97, 5345 (1975)

43. O. Pieroni, A. Fissi, S. Merlino, and F. Ciardelli, Isr. J. Chem., 15, $22(1976 / 1977)$.

44. O. Pieroni, G. Montagnoli, A. Fissi, S. Merlino, and F. Ciadrelli, J. Am. Chem. Soc., 97, 6820 (1975).

45. B. R. Malcolm and M. D. Walkinshaw, Biopolymers, 25, 607 (1986).

46. C. Toniolo, G. M. Bonora, A. Bavoso, E. Benedetti, B. Di Blasio, V. Pavone, and C. Pedone, Macromolecules, 19, 472 (1986).

47. D. J. Barlow and J. M. Thronton, J. Mol. Biol., 201, 601 (1988).

48. E. E. Hodgkin, J. D. Clark, K. R. Miller, and G. R. Marshall, Biopolymers, 30, 533 (1990).

49. S. J. Leach, G. Nemethy, and H. A. Scheraga, Biopolymers, 4, 887 (1966).

50. S. Arnott and A. J. Wonacott, J. Mol. Biol., 21, 317 (1966).

51. T. Blundell, D. Barlow, N. Borkakoti, and J. Thornton, Nature, 306, 218 (1983)

52. E. K. S. Viayakumar and P. Balaram, Tetrahedron, 39, 2725 (1983).

53. I. L. Karle, J. L. Filppen-Anderson, K. Uma, H. Balaram, and P. Balaram, Proc. Natl. Acad. Sci. U.S.A., 86, 765 (1989).

54. E. Benedetti, D. B. Benedetto, V. Pavone, C. Pedone, A. Santini, A. Bavoso, C. Toniolo, M. Crisma, and L. Sartore, J. Chem. Soc., Perkin Trans. 2, 1829 (1990).

55. V. Pavone, E. Benedetti, B. DiBlasio, C. Pedone, A. Santini, A. Bavoso, C. Toniolo, M. Crisma, and L. Sartore, J. Biomol. Struct. Dynam., 7, 1321 (1990).

57. K. Otoda, Y. Kitagawa, S. Kimura, and Y. Imanishi, Biopolymers, 33, 1337 (1993).

58. G. Basu and A. Kuki, Biopolymers, 32, 61 (1992).

59. E. E. Hodgin, J. D. Clark, K. R. Miller, and G. R. Marshall, Biopolymers, 30, 533 (1990). 